\title{
Unravelling spiral cleavage
}

José M. Martín-Durán (1)*, Ferdinand Marlétaz (2)

(1) Queen Mary, University of London. School of Biological and Chemical Sciences. Mile End Road. E1 4NS London. United Kingdom

(2) Molecular Genetics Unit, Okinawa Institute of Science \& Technology, 1919-1 Tancha, Onna 904-0495, Japan

* Corresponding author (hema.martin@qmul.ac.uk)

\section{Summary}

Snails, earthworms, and flatworms are remarkably different animals, but they all exhibit a very similar mode of early embryogenesis, called spiral cleavage. This is one of the most widespread developmental programs in animals, probably ancestral to almost half of the animal phyla, and therefore its study is essential to understand animal development and evolution. However, our knowledge of spiral cleavage is still in its infancy. Recent technical and conceptual advances, such as the establishment of genome editing and improved phylogenetic resolution, are paving the way for a fresher and deeper look into this fascinating early cleavage mode.

\section{Introduction}

Spiral cleavage is a distinctive early developmental program displayed by at least eight major animal groups, including annelids (i.e. segmented worms), molluscs (e.g. snails), nemerteans (i.e. ribbon worms) and platyhelminths (i.e. flatworms) (Hejnol, 2010, Henry, 2014, Lambert, 2010) (Fig. 1A). Often mistakenly regarded as the typical cleavage pattern of protostomian lineages, spiral cleavage is instead unique to and probably a synapomorphy (ancestral characteristic) of Spiralia (= Lophotrochozoa sensu lato, see below) (Halanych et al., 1995, Giribet, 2008). Spiralia are a morphologically and ecologically diverse group comprising around $10 \%$ of the known animal species (Brusca et al., 2016). From a developmental perspective, spiral cleavage is characterised by a $45^{\circ}$ shift in the mitotic spindle with respect 
to the animal-vegetal axis in the transition from 4- to 8-cell stage (Fig. 1B, C), yet the chirality of this shift might be determined already in the zygote (Meshcheryakov and Beloussov, 1975, Abe and Kuroda, 2019). This shift persists in subsequent divisions, each time alternating directions, either dextrally or sinistrally. Eventually, this results in the cells located at the animal pole of the embryo displaying a compact, spiral-like arrangement, hence the name of the cleavage program (Fig. 1D). In the 19th century, the study of spiral cleavage boosted the study of embryonic cell lineages and supported the use of embryonic data to reconstruct animal relationships (Wilson, 1898, Guralnick, 2002, Maienschein, 1990). The emergence of prominent invertebrate model systems that are not spiral cleavers (such as the fruit fly $D$. melanogaster or the nematode C. elegans, both belonging to Ecdysozoa: the moulting animals) made the study of spiral cleavage lag behind, and ultimately become one of the most under investigated, yet widespread developmental strategies in animals. However, we know today that Ecdysozoa has undergone extensive loss of characters (e.g. ciliated epithelia, many gene families, introns) that are preserved between Spiralia and Deuterostomia (Luo et al., 2018, Wang et al., 2017, Roy and Irimia, 2008), the third major clade of bilaterally symmetrical animals to which vertebrates and humans belong. Therefore, spiralians are important organisms, not only because their unique spiral cleavage enables to tackle fundamental questions in developmental biology, but also because their phylogenetic position provides a unique window on the bilaterian ancestry.

This Spotlight article aims to briefly capture the resurgence that the study of spiral cleavage is experiencing in recent years. Plummeting sequencing prices together with the establishment of molecular and functional experimental approaches in a growing number of species (Neal et al., 2019, Perry and Henry, 2015, Abe and Kuroda, 2019, Zantke et al., 2014) is taking the study of this early developmental program out of the ostracism. We start this Spotlight with a general overview of the phylogeny of Spiralia and of the species emerging as laboratory research systems, followed by a discussion of some of the features of spiral cleavage that make it uniquely suited to study fundamental questions in developmental biology. We end with a personal perspective on where the study of spiral cleavage and spiralians generally should move to and what we believe is needed to keep bringing spiralians to the forefront of embryological and evolutionary research. 


\section{Spiralian phylogeny: new certainties and lingering doubts}

Thirty years ago, the advent of molecular phylogenetics progressively established the subdivision of bilaterally symmetrical animals (Bilateria) into three main superclades: Deuterostomia, Ecdysozoa, and Lophotrochozoa (Field et al., 1988, Halanych et al., 1995). By bringing together disparate animal groups such as flatworms, annelids and molluscs, molecular data confirmed what embryologists had suspected for a long time based on the shared presence of spiral cleavage (Schleip, 1929). However, Lophotrochozoa was originally defined as the clade containing all descendants of the last common ancestor of animals with a lophophore (horseshoe-shaped band of ciliated tentacles around the mouth) and/or trochophore (ciliated planktonic larva), without specifying these descendant's lineages or their relationships in detail (Halanych et al., 1995). The possibility that groups such as Platyhelminthes and Rotifera diverged prior to the ancestor of lophophorates and trochozoans prompted some authors to refer instead to the third domain of Bilateria as Spiralia, and to consider Lophotrochozoa only as its subclade (Giribet, 2008).

At the origin of this naming debate lies the difficulty to accurately reconstruct the internal relationships of Spiralia and the lack of embryological knowledge for many of the more obscure spiralian lineages. Groups such as Platyhelminthes, Gastrotricha and Gnathostomulida have some of the fastest rates of molecular evolution among animals, which causes phylogenetic reconstruction artefacts such as long branch attraction that impede the inference of a proper spiralian tree. Recently, several studies have attempted to tackle these issues by expanding the taxon and character repertoire, and more importantly by using better inference methods (Marletaz et al., 2019, Laumer et al., 2019, Kocot et al., 2017), in particular the CAT model, which defines evolutionary profiles capturing the diversity of composition and substitution processes among sites (Rodrigue and Lartillot, 2014). These studies have uncovered a new animal clade ('Gnathifera') within Spiralia, uniting the enigmatic chaetognaths, rotifers, and other neglected lineages, such as gnathostomulids and micrognathozoa (Fig. 2A). Sister-group to the other spiralians, the clade 'Gnathifera' (jawbearers) refers to the complex jaw apparatus present in these groups. Strikingly, only Gnathostomulida (“jaw worms") exhibit spiral cleavage within this group (Riedl, 1969), and this needs to be taken with caution, as the single original description of spiral cleavage in these organisms has not been reassessed with more modern methodologies. If confirmed, this will be of uttermost importance, as it will support considering spiral cleavage a synapomorphy to the entire clade, thus the Spiralia naming. 
Other areas of the Spiralia phylogenetic tree remain, however, strongly disputed depending on methodological choices made in distinct studies. First, the association of Mollusca, the most diverse spiralian group, with Entoprocta (a small clade of mostly sessile and colonial marine animals) in 'Tetraneuralia' is only recovered in studies without the fastest evolving taxa (Marletaz et al., 2019) (Fig. 2A). Similarly, an unexpected association of Platyhelminthes, Nemertea and Annelida (Fig. 2A) contrasts with the association of Platyhelminthes with Gastrotricha ('Rouphozoa', Fig. 2B) when more inclusive datasets are used (Laumer et al., 2019). Attempts to resolve these disputes with dataset recoding, whereby individual amino acids are fused into broad biochemical categories, have proven controversial (Hernandez and Ryan, 2019), but nevertheless have not significantly changed the results reported in the most recent studies (Marletaz et al., 2019, Laumer et al., 2019). Despite all these uncertainties, all current phylogenies support considering spiral cleavage at least ancestral to the sister clade to Gnathifera and present an intricate story of repeated losses of spiral cleavage (Fig. 2A, B; discussed below). This broad phylogenetic framework offers a unique opportunity to explore to what extent a cleavage program present in disparate animals that have diverged over millions of years has remained conserved at different levels of biological complexity. Moreover, it also poses multiple exciting cases of transition from spiral to radial cleavage, ideal cases to explore the relationship between early division patterns, cell lineages and fate specification gene networks.

\section{Spiralian research systems}

Spiral cleavage has been studied in a myriad of species, yet in most of the cases the studies are limited to a basic description of the cell lineage. Compared to other areas of biosciences and developmental biology, where a handful of species have become pillars for experimental research (e.g. in vertebrates, arthropods and nematodes), this can be unsettling. This diversity has come with advantages and disadvantages, and it is probably related to the large number of major animal groups exhibiting spiral cleavage, each with distinctive body plans and evolutionary histories that make them fascinating on their own. At the methodological level, the annelid worms Platynereis dumerilii, Capitella teleta and Helobdella robusta, as well as the gastropod mollusc Crepidula fornicata are arguably the most settled spiralian research systems (Henry, 2014), with established modern functional (e.g. CRISPR and transgenesis) and imaging approaches (Neal et al., 2019, Perry and Henry, 2015, Zantke et al., 2014, Gline et al., 2011, Song et al., 2002) (Table 1). However, a broad range of other spiralian species have been or are being used to study spiral cleavage employing molecular approaches, 
including - but not limited to - the annelids Owenia fusiformis and Streblospio benedicti (Zakas et al., 2018, Martin-Duran et al., 2018, Weisblat and Kuo, 2014); the molluscs Tritia (= Ilyanassa) obsoleta, Biomphalaria glabrata, Patella vulgata, Lymnaea stagnalis, Antalis entalis, and Acanthochitona crinita (Wanninger and Wollesen, 2018, Abe and Kuroda, 2019, Lambert and Nagy, 2001, Grande and Patel, 2009, Damen and Dictus, 1994); the nemerteans Cerebratulus lacteus, Lineus ruber and Micrura alaskensis (Martin-Duran et al., 2018, Hiebert and Maslakova, 2015, Henry et al., 2008); the flatworm Prostheceraeus crozieri (Girstmair and Telford, 2019); and other spiralian species that have secondarily lost spiral cleavage, such as cephalopod molluscs (Tarazona et al., 2019), the bryozoan Membranipora membranacea (Vellutini et al., 2017), and the brachiopods Terebratalia transversa and Novocrania anomala (Martin-Duran et al., 2016). This combination of established and emerging research systems covering most major lineages of Spiralia is bringing a more comprehensive understanding of spiral cleavage, of the plasticity and regularities of this mode of development, and of the mechanisms that generate a vast diversity of morphological outcomes from a widely shared embryonic program. However, it also implies that research communities working on a given species are generally small. Therefore, raising some of these organisms to an experimental level comparable to other established research systems outside Spiralia is taking time.

\section{How can spiral cleavage contribute to modern developmental biology?}

Its broad phylogenetic distribution among vastly diverse animal lineages (Fig. 2) together with its likely common origin and overall conservation make spiral cleavage a unique developmental program in animals. Several studies have already demonstrated the importance of studying spiral cleavage to infer ancestral developmental characters to bilaterally symmetrical animals (Martin-Duran et al., 2018, Martin-Duran et al., 2016, Grande and Patel, 2009, Henry et al., 2008). Probably, the best example is that of the transforming growth factor $\beta$ (TGF- $\beta$ ) ligand Nodal, which controls left-right (LR) axis specification and mesodermal patterning in echinoderms and chordates (i.e. Deuterostomia) and was long considered to be a deuterostomian innovation due to its absence in arthropods and nematodes (Chea et al., 2005). The identification of Nodal in molluscs and other spiralians (Grande and Patel, 2009, Grande et al., 2014), and the characterisation of its role in the development of the LR axis in these organisms demonstrated instead that the LR patterning role of the Nodal signalling pathway likely dates back to the last common bilaterian ancestor and was secondarily lost in the lineage leading to flies and roundworms. 
However, the impact of spiral cleavage goes beyond providing an evolutionary perspective to developmental biology. As we illustrate below, spiral cleavage is also a powerful research system to explore fundamental questions in developmental biology.

\section{Stasis and change in early embryonic cell lineages}

Key ontogenetic aspects are broadly conserved in spiral cleaving embryos. Probably the most obvious ones are the subdivision of the embryo in four quadrants, named from A to D (Fig. 1B) and the distinctive twist of the asymmetric mitotic spindle from the 8-cell stage onwards. In addition, cells are usually smaller on the animal pole (the micromeres, named with lowercase letters, a to d) and larger on the vegetal pole of the embryo (the macromeres, named with upper case letters, A to D) (Fig. 1C). How these attributes have remained static over the course of $\sim 500$ million years across animal lineages with markedly different evolutionary trajectories is still a mystery, but some studies indicate that despite the overall conservation at the cellular level, the underpinning molecular mechanisms controlling these basic features of spiral cleavage might vary. For instance, the first asymmetric zygotic division in clitellate annelids is controlled by either inherited monastral spindles or the transient downregulation of one of the centrosomes (Ren and Weisblat, 2006). Likewise, the chirality of the shift in the mitotic spindle between the 4- and 8-cell stages is controlled by a tandemly duplicated diaphanous-related formin gene in the pond snail Lymnaea stagnalis (Davison et al., 2016, Abe and Kuroda, 2019, Kuroda et al., 2016). However, this duplication event is not ancestral to molluscs or even gastropods, and while one of the copies carries a frame-shift mutation in Lymnaea, both appear to be functional in the terrestrial pulmonate snail Bradybaena similaris (Noda et al., 2019).

The conservation of the spiral cleavage pattern is also related to an overall similarity in the fates of major embryonic regions. Quadrants A to D tend to generate left, ventral, right and dorsal embryonic areas respectively, and the animal-vegetal embryonic axis roughly correlates with the anteroposterior axis. However, the detailed embryonic cell lineages and precise cell fate specification strategies may differ among spiral cleaving embryos (Nielsen, 2005, Nielsen, 2004). For instance, a population of cells referred to as "ectomesoderm", which often contributes to anterior mesodermal structures, derive from the third tier of micromeres of the quadrants $\mathrm{A}$ and $\mathrm{B}$ (the $3 \mathrm{a}$ and $3 \mathrm{~b}$ micromeres) in nemertean worms and the mollusc Patella, but the second tier of the quadrant B ( $2 \mathrm{~b}$ micromere) in flatworms, the micromeres $3 \mathrm{a}$ and $3 \mathrm{~b}$ in the mollusc $C$. fornicata, and the micromeres $3 \mathrm{a}, 3 \mathrm{c}, 3 \mathrm{~d}, 4 \mathrm{~d}$ and 
possibly 2a, 2c and 3b in the annelid C. teleta (Meyer et al., 2010, Nielsen, 2005, Nielsen, 2004, Hejnol et al., 2007). Similarly, the overall specification of these cell fates can be strongly controlled by maternal determinants in the so-called unequal or autonomous spiral cleaving species, or rely more on inductive cell-cell interactions in the so-called equal or determinative spiral cleaving species (Henry, 2014). Although classic analyses do not rely on intracellular lineage tracing and need to be taken with caution, cell lineages in spiral cleavage appear to be overall far more labile than often depicted, which might form the basis for the morphological diversity of spiralians, yet the mechanisms accounting for this diversity are still poorly understood.

Spiral cleavage has also been lost numerous times over the course of evolution, sometimes to diverge into bizarre cleavage modes, as in many flatworms (Martin-Duran and Egger, 2012), sometimes to reverse to either holoblastic (e.g. in bryozoans and brachiopods) or superficial (e.g.in cephalopods) radially symmetrical patterns (Hejnol, 2010) (Fig. 2). In the bryozoan Membranipora membranacea, the loss of the spiral-like arrangement of cells during early development did not affect the overall embryonic cell lineage (Vellutini et al., 2017), which remained similar to that of other spiral cleaving relatives, further supporting that cleavage and cell fates are, or can be to a certain extent decoupled in some members of Spiralia. This condition significantly differs from other known cases in animal development with highly stereotypical cell division patterns, such as ascidian (Guignard et al., 2018) and ctenophore embryogenesis (Martindale and Henry, 1999), where cellular arrangements and cell fates are tightly linked. Therefore, spiralians and spiral cleavage can provide a window on the cellular and molecular mechanisms controlling and generating plasticity in embryonic cell fates.

\section{The cellular and molecular control of embryonic patterning}

The extensive knowledge of the spiralian cell lineages contrasts with the relatively poor understanding of the gene regulatory networks governing embryonic patterning generally. As mentioned above, LR chirality in gastropod molluscs is under control of early maternally supplied cytoskeleton components that ultimately determine blastomere chirality at the 8-cell stage and the site of expression of the Nodal-Pitx signalling pathway (Abe and Kuroda, 2019, Kuroda et al., 2009). However, the extent to which these mechanisms are conserved among spiralians is unclear, since some lineages have lost the Nodal ligand (Grande et al., 2014), and the upstream cytoskeleton components appear to vary even among gastropods (Davison et al., 2016, Noda et al., 2019). Moreover, the cytoskeleton and mitotic spindle appear to 
underpin the differential segregation of mRNAs during spiral cleavage, ultimately controlling micromere quartet identity (Kingsley et al., 2007, Lambert and Nagy, 2002, Rabinowitz and Lambert, 2010).

As in other animal embryos, anteroposterior (AP) and dorsoventral (DV) patterning are intimately linked in spiral cleavage. Descendants of the D quadrant (3D in some molluscs, 2d and $4 \mathrm{~d}$ micromeres in the annelid Tubifex, but the 2D macromere in the annelid Capitella teleta) act as posterodorsal embryonic organiser, controlling the development of the other embryonic fates and bilateral axial identities (Henry, 2014, Hejnol, 2010, Lambert, 2010, Amiel et al., 2013, Nakamoto et al., 2011). In mollusc and some annelid embryos (e.g. Hydroides hexagonus), the MAPK signalling pathway is active in the D lineage and is often involved in the specification activity of the posterodorsal embryonic organiser (Lambert and Nagy, 2001, Lambert and Nagy, 2003, Koop et al., 2007, Henry and Perry, 2008). In most animal embryos, the canonical Wnt signalling pathway and the bone morphogenic protein (BMP) signalling pathway are often involved in AP and DV specification respectively, but they appear to exert lineage specific roles in spiralians. For example, canonical Wnt signalling controls binary cell decisions during cleavage in the annelid P. dumerilii (Schneider and Bowerman, 2007), but it primarily regulates endomesoderm specification (i.e. gastrulation) in C. fornicata, the nemertean C. lacteus and brachiopod embryos (MartinDuran et al., 2016, Henry et al., 2008, Henry et al., 2010). Similarly, the BMP pathway controls dorsoventral patterning in the mollusc Tritia (= Ilyanassa) obsoleta and brachiopod embryos (Martin-Duran et al., 2016, Lambert et al., 2016), but it does not in the annelid $C$. teleta, where it is instead the Activin/Nodal signalling pathway that plays that function (Lanza and Seaver, 2018). As with embryonic cell fates, these data indicate that there is variation in the way spiralian embryos are patterned beneath the highly conserved program of cell divisions, yet the exact extent of these differences and how they relate to changes in embryonic cell fates is unclear.

\section{The evolution of cell types and morphological novelties}

Comprising 15 out of the 32 recognised major animal groups (or Phyla under Linnaean taxonomy), Spiralia is a morphologically and ecologically diverse animal group. Each defined by a relatively distinct body plan, some of these groups are among the most diversified animal clades, such as Platyhelminthes, Mollusca and Annelida. Not surprisingly, there are countless examples of morphological innovations in Spiralia, some of them amongst 
the most iconic in the animal tree of life, such as the molluscan shells (Wanninger and Wollesen, 2018), and others less known but equally exciting, such as the annelid and brachiopod chaetae (Schiemann et al., 2017), and the molluscan and brachiopod cartilage (Tarazona et al., 2016). What distinguishes spiralians from other vastly diverse animal groups, such as arthropods and vertebrates is that, to a large extent, this morphological diversity emerges through the same early spiral cleavage program. For developmental biology this is of great importance, because embryos of very distantly related and morphologically different species can be perfectly matched at a single-cell resolution, allowing to identify precisely the cellular and molecular mechanisms driving morphological change. For instance, molluscan shells emerge from derivatives of the $2 \mathrm{a}-2 \mathrm{~d}$ micromere quartet (Mohri et al., 2016, Chan and Lambert, 2014, Lyons et al., 2015), which form an initial cluster of ectodermal cells, the "shell field", that will differentiate into a novel cell type with biomineralising potential (Wanninger and Wollesen, 2018). However, the $2 \mathrm{~d}$ micromere and its progeny generates the majority of the segmented trunk ectoderm and the ventral nerve cords in annelids, where they do not differentiate into biomineralising cell types (Meyer et al., 2010). The expression of the transcription factor engrailed appears to be an early signal that demarcates the shell field from the rest of the dorsal ectoderm in molluscs (Jacobs et al., 2000), but the upstream mechanisms that generate this divergence in spiral development between molluscs and other spiral cleaving groups are unknown.

Spiralia is also important to explore the developmental principles governing convergent evolution and gain/loss of morphological traits, even at late ontogenetic stages when differences amongst embryos are more pronounced. For instance, heavily centralised brain centres and/or medially condensed nerve cords evolved secondarily in spiralian groups such as annelids, molluscs and flatworms (Martin-Duran et al., 2018), and so did the complex eyes and the body appendages of cephalopods (Tarazona et al., 2019). While in some cases, divergence in the molecular repertoire underpin the development of similar structures, such as neuronal cell types and nerve cords (Martin-Duran et al., 2018), the recruitment of relatively well conserved ancestral gene networks govern others, as in the parallel evolution of cephalopod arms (Tarazona et al., 2019). Altogether, these few examples illustrate how spiralians and spiral cleavage may contribute to our understanding of how very similar developmental strategies generate phenotypic diversity, as well as of the mechanisms governing the repeated emergence of similar phenotypic outcomes. 


\section{Perspectives}

Despite recent advances, major questions remain open in spiralian embryology: when did spiral cleavage evolve? What are the molecular and cellular mechanisms governing spiral cleavage? Are these mechanisms as conserved as the stereotypical cleavage program suggests, or is there widespread developmental variation hidden under a stable cell division program? If the latter, how do developmental programs diversify as the overall cell division patterns remain? And how does morphological diversity emerge from such a priori stable early embryonic program? The breadth of stimulating developmental questions that the study of spiral cleavage poses is virtually unlimited; as is its capacity to enlighten fundamental biological concepts. However, in order to answer these questions, we need a more solid phylogenetic framework of the interrelationships between spiralian groups, and reassess the embryonic development of certain enigmatic groups, in particular gnathostomulids. One can hope that improved genomic resources and particularly full genome sequences in all spiralian lineages would help to resolve some of the issues plaguing phylogenomic studies, such as contamination and missing data. This would represent a challenge as many microscopic lineages (e.g. micrognathozoa, gastrotrichs) will prove difficult to sequence, but this endeavour likely represents the next milestone for spiralian phylogeny.

In parallel with phylogenetic efforts, the continued pursuit of more research systems with better genomes and -omics datasets, as well as more functional (e.g. CRISPR and transgenesis) and imaging methodologies, will allow us to dig deeper into the nuts and bolts of spiral cleavage. However, we need to keep promoting and taking advantage of the thriving diversity of organisms employed by the spiralian research community, as it is also the key to attain a comprehensive perspective on the mechanisms and evolution of this mode of development. Ultimately, this will require a multidisciplinary and coordinated community effort, but the possibility to unwind the mysteries of spiral cleavage is definitely worth the effort.

\section{Acknowledgements}

We would like to thank members of the Martín-Durán lab, Bruno C. Vellutini and Daria Gavriouchkina for discussions and critically reading this manuscript. JMM-D is supported by an ERC Starting Grant (action number 801669). FM is supported by institutional funding of the Okinawa Institute of Science \& Technology \& JSPS Kakenhi Grant. 


\section{References}

ABE, M. \& KURODA, R. 2019. The development of CRISPR for a mollusc establishes the formin Lsdial as the long-sought gene for snail dextral/sinistral coiling. Development, 146.

ABE, M., SHIMIZU, M. \& KURODA, R. 2009. Expression of exogenous fluorescent proteins in early freshwater pond snail embryos. Dev Genes Evol, 219, 167-73.

AMIEL, A. R., HENRY, J. Q. \& SEAVER, E. C. 2013. An organizing activity is required for head patterning and cell fate specification in the polychaete annelid Capitella teleta: new insights into cell-cell signaling in Lophotrochozoa. Dev Biol, 379, 107-22.

BEZARES-CALDERON, L. A., BERGER, J., JASEK, S., VERASZTO, C., MENDES, S., GUHMANN, M., ALMEDA, R., SHAHIDI, R. \& JEKELY, G. 2018. Neural circuitry of a polycystin-mediated hydrodynamic startle response for predator avoidance. Elife, 7.

BRUSCA, R., MOORE, W. \& SHUSTER, S. 2016. Invertebrates, Oxford University Press.

CHAN, X. Y. \& LAMBERT, J. D. 2014. Development of blastomere clones in the Ilyanassa embryo: transformation of the spiralian blastula into the larval body plan. Dev Genes Evol, 224, 159-74.

CHEA, H. K., WRIGHT, C. V. \& SWALLA, B. J. 2005. Nodal signaling and the evolution of deuterostome gastrulation. Dev Dyn, 234, 269-78.

DAMEN, P. \& DICTUS, W. J. 1994. Cell lineage of the prototroch of Patella vulgata (Gastropoda, Mollusca). Dev Biol, 162, 364-83.

DAVISON, A., MCDOWELL, G. S., HOLDEN, J. M., JOHNSON, H. F., KOUTSOVOUlOS, G. D., LIU, M. M., HULPIAU, P., VAN ROY, F., WADE, C. M., BANERJEE, R., YANG, F., CHIBA, S., DAVEY, J. W., JACKSON, D. J., LEVIN, M. \& BLAXTER, M. L. 2016. Formin Is Associated with Left-Right Asymmetry in the Pond Snail and the Frog. Curr Biol, 26, 654-60.

FIELD, K. G., OLSEN, G. J., LANE, D. J., GIOVANNONI, S. J., GHISELIN, M. T., RAFF, E. C., PACE, N. R. \& RAFF, R. A. 1988. Molecular phylogeny of the animal kingdom. Science, 239, 748-53.

GIRIBET, G. 2008. Assembling the lophotrochozoan (=spiralian) tree of life. Philos Trans $R$ Soc Lond B Biol Sci, 363, 1513-22. 
GIRSTMAIR, J. \& TELFORD, M. J. 2019. Reinvestigating the early embryogenesis in the flatworm Maritigrella crozieri highlights the unique spiral cleavage program found in polyclad flatworms. Evodevo, 10, 12.

GLINE, S. E., NAKAMOTO, A., CHO, S. J., CHI, C. \& WEISBLAT, D. A. 2011. Lineage analysis of micromere 4d, a super-phylotypic cell for Lophotrochozoa, in the leech Helobdella and the sludgeworm Tubifex. Dev Biol, 353, 120-33.

GRANDE, C., MARTIN-DURAN, J. M., KENNY, N. J., TRUCHADO-GARCIA, M. \& HEJNOL, A. 2014. Evolution, divergence and loss of the Nodal signalling pathway: new data and a synthesis across the Bilateria. Int J Dev Biol, 58, 521-32.

GRANDE, C. \& PATEL, N. H. 2009. Nodal signalling is involved in left-right asymmetry in snails. Nature, 457, 1007-11.

GUIGNARD, L., FIUZA, U.-M., LEGGIO, B., FAURE, E., LAUSSU, J., HUFNAGEL, L., MALANDAIN, G., GODIN, C. \& LEMAIRE, P. 2018. Contact-dependent cell-cell communications drive morphological invariance during ascidian embryogenesis. bioRxiv, 238741.

GURALNICK, R. 2002. A Recapitulation of the Rise and Fall of the Cell Lineage Research Program: The Evolutionary-Developmental Relationship of Cleavage to Homology, Body Plans and Life History. Journal of the History of Biology, 35, 537-567.

HALANYCH, K. M., BACHELLER, J. D., AGUINALDO, A. M., LIVA, S. M., HILLIS, D. M. \& LAKE, J. A. 1995. Evidence from 18S ribosomal DNA that the lophophorates are protostome animals. Science, 267, 1641-3.

HEJNOL, A. 2010. A twist in time--the evolution of spiral cleavage in the light of animal phylogeny. Integr Comp Biol, 50, 695-706.

HEJNOL, A., MARTINDALE, M. Q. \& HENRY, J. Q. 2007. High-resolution fate map of the snail Crepidula fornicata: the origins of ciliary bands, nervous system, and muscular elements. Dev Biol, 305, 63-76.

HENRY, J. J. \& PERRY, K. J. 2008. MAPK activation and the specification of the D quadrant in the gastropod mollusc, Crepidula fornicata. Dev Biol, 313, 181-95.

HENRY, J. Q. 2014. Spiralian model systems. Int J Dev Biol, 58, 389-401.

HENRY, J. Q., PERRY, K. J. \& MARTINDALE, M. Q. 2010. beta-catenin and early development in the gastropod, Crepidula fornicata. Integr Comp Biol, 50, 707-19.

HENRY, J. Q., PERRY, K. J., WEVER, J., SEAVER, E. \& MARTINDALE, M. Q. 2008. Beta-catenin is required for the establishment of vegetal embryonic fates in the nemertean, Cerebratulus lacteus. Dev Biol, 317, 368-79. 
HERNANDEZ, A. M. \& RYAN, J. F. 2019. Six-state amino acid recoding is not an effective strategy to offset the effects of compositional heterogeneity and saturation in phylogenetic analyses. bioRxiv, 729103.

HIEBERT, L. S. \& MASLAKOVA, S. A. 2015. Hox genes pattern the anterior-posterior axis of the juvenile but not the larva in a maximally indirect developing invertebrate, Micrura alaskensis (Nemertea). BMC Biology, 13, 23.

JACOBS, D. K., WRAY, C. G., WEDEEN, C. J., KOSTRIKEN, R., DESALLE, R., STATON, J. L., GATES, R. D. \& LINDBERG, D. R. 2000. Molluscan engrailed expression, serial organization, and shell evolution. Evol Dev, 2, 340-7.

KINGSLEY, E. P., CHAN, X. Y., DUAN, Y. \& LAMBERT, J. D. 2007. Widespread RNA segregation in a spiralian embryo. Evol Dev, 9, 527-39.

KOCOT, K. M., STRUCK, T. H., MERKEL, J., WAITS, D. S., TODT, C., BRANNOCK, P. M., WEESE, D. A., CANNON, J. T., MOROZ, L. L., LIEB, B. \& HALANYCH, K. M. 2017. Phylogenomics of Lophotrochozoa with Consideration of Systematic Error. Syst Biol, 66, 256-282.

KOOP, D., RICHARDS, G. S., WANNINGER, A., GUNTER, H. M. \& DEGNAN, B. M. 2007. The role of MAPK signaling in patterning and establishing axial symmetry in the gastropod Haliotis asinina. Dev Biol, 311, 200-12.

KURODA, R., ENDO, B., ABE, M. \& SHIMIZU, M. 2009. Chiral blastomere arrangement dictates zygotic left-right asymmetry pathway in snails. Nature, 462, 790-4.

KURODA, R., FUJIKURA, K., ABE, M., HOSOIRI, Y., ASAKAWA, S., SHIMIZU, M., UMEDA, S., ICHIKAWA, F. \& TAKAHASHI, H. 2016. Diaphanous gene mutation affects spiral cleavage and chirality in snails. Sci Rep, 6, 34809.

LAMBERT, J. D. 2010. Developmental patterns in spiralian embryos. Curr Biol, 20, R72-7.

LAMBERT, J. D., JOHNSON, A. B., HUDSON, C. N. \& CHAN, A. 2016. Dpp/BMP2-4 Mediates Signaling from the D-Quadrant Organizer in a Spiralian Embryo. Curr Biol, 26, 2003-2010.

LAMBERT, J. D. \& NAGY, L. M. 2001. MAPK signaling by the D quadrant embryonic organizer of the mollusc Ilyanassa obsoleta. Development, 128, 45-56.

LAMBERT, J. D. \& NAGY, L. M. 2002. Asymmetric inheritance of centrosomally localized mRNAs during embryonic cleavages. Nature, 420, 682-6.

LAMBERT, J. D. \& NAGY, L. M. 2003. The MAPK cascade in equally cleaving spiralian embryos. Dev Biol, 263, 231-41. 
LANZA, A. R. \& SEAVER, E. C. 2018. An organizing role for the TGF-beta signaling pathway in axes formation of the annelid Capitella teleta. Dev Biol, 435, 26-40.

LAUMER, C. E., FERNANDEZ, R., LEMER, S., COMBOSCH, D., KOCOT, K. M., RIESGO, A., ANDRADE, S. C. S., STERRER, W., SORENSEN, M. V. \& GIRIBET, G. 2019. Revisiting metazoan phylogeny with genomic sampling of all phyla. Proc Biol Sci, 286, 20190831.

LUO, Y. J., KANDA, M., KOYANAGI, R., HISATA, K., AKIYAMA, T., SAKAMOTO, H., SAKAMOTO, T. \& SATOH, N. 2018. Nemertean and phoronid genomes reveal lophotrochozoan evolution and the origin of bilaterian heads. Nat Ecol Evol, 2, 141151.

LYONS, D. C., PERRY, K. J. \& HENRY, J. Q. 2015. Spiralian gastrulation: germ layer formation, morphogenesis, and fate of the blastopore in the slipper snail Crepidula fornicata. Evodevo, 6, 24.

MAIENSCHEIN, J. 1990. Defining Biology: Lectures from the 1890's, Harvard University Press.

MARLETAZ, F., PEIJNENBURG, K., GOTO, T., SATOH, N. \& ROKHSAR, D. S. 2019. A New Spiralian Phylogeny Places the Enigmatic Arrow Worms among Gnathiferans. Curr Biol, 29, 312-318 e3.

MARTIN-DURAN, J. M. \& EGGER, B. 2012. Developmental diversity in free-living flatworms. Evodevo, 3, 7.

MARTIN-DURAN, J. M., PANG, K., BORVE, A., LE, H. S., FURU, A., CANNON, J. T., JONDELIUS, U. \& HEJNOL, A. 2018. Convergent evolution of bilaterian nerve cords. Nature, 553, 45-50.

MARTIN-DURAN, J. M., PASSAMANECK, Y. J., MARTINDALE, M. Q. \& HEJNOL, A. 2016. The developmental basis for the recurrent evolution of deuterostomy and protostomy. Nat Ecol Evol, 1, 5.

MARTINDALE, M. Q. \& HENRY, J. Q. 1999. Intracellular fate mapping in a basal metazoan, the ctenophore Mnemiopsis leidyi, reveals the origins of mesoderm and the existence of indeterminate cell lineages. Dev Biol, 214, 243-57.

MASLAKOVA, S. A., MARTINDALE, M. Q. \& NORENBURG, J. L. 2004. Fundamental properties of the spiralian developmental program are displayed by the basal nemertean Carinoma tremaphoros (Palaeonemertea, Nemertea). Dev Biol, 267, $342-$ 60. 
MESHCHERYAKOV, V. \& BELOUSSOV, L. 1975. Asymmetrical rotations of blastomeres in early cleavage of Gastropoda. Wilhelm Roux's Archives, 177, 193-203.

MEYER, N. P., BOYLE, M. J., MARTINDALE, M. Q. \& SEAVER, E. C. 2010. A comprehensive fate map by intracellular injection of identified blastomeres in the marine polychaete Capitella teleta. Evodevo, 1, 8.

MOHRI, M., HASHIMOTO, N. \& WADA, H. 2016. Lineage tracing of the bivalve shell field with special interest in the descendants of the $2 \mathrm{~d}$ blastomere. Biol Lett, 12, 20151055.

NAKAMOTO, A., NAGY, L. M. \& SHIMIZU, T. 2011. Secondary embryonic axis formation by transplantation of D quadrant micromeres in an oligochaete annelid. Development, 138, 283-90.

NEAL, S., DE JONG, D. M. \& SEAVER, E. C. 2019. CRISPR/CAS9 mutagenesis of a single r-opsin gene blocks phototaxis in a marine larva. Proc Biol Sci, 286, 20182491.

NIELSEN, C. 2004. Trochophora larvae: cell-lineages, ciliary bands, and body regions. 1. Annelida and Mollusca. J Exp Zool B Mol Dev Evol, 302, 35-68.

NIELSEN, C. 2005. Trochophora larvae: cell-lineages, ciliary bands and body regions. 2 . Other groups and general discussion. J Exp Zool B Mol Dev Evol, 304, 401-47.

NODA, T., SATOH, N. \& ASAMI, T. 2019. Heterochirality results from reduction of maternal diaph expression in a terrestrial pulmonate snail. Zoological Lett, 5, 2.

OZPOLAT, B. D., HANDBERG-THORSAGER, M., VERVOORT, M. \& BALAVOINE, G. 2017. Cell lineage and cell cycling analyses of the $4 \mathrm{~d}$ micromere using live imaging in the marine annelid Platynereis dumerilii. Elife, 6.

PERRY, K. J. \& HENRY, J. Q. 2015. CRISPR/Cas9-mediated genome modification in the mollusc, Crepidula fornicata. Genesis, 53, 237-44.

RABINOWITZ, J. S. \& LAMBERT, J. D. 2010. Spiralian quartet developmental potential is regulated by specific localization elements that mediate asymmetric RNA segregation. Development, 137, 4039-49.

REN, X. \& WEISBLAT, D. A. 2006. Asymmetrization of first cleavage by transient disassembly of one spindle pole aster in the leech Helobdella robusta. Developmental Biology, 292, 103-115.

RIEDL, R. J. 1969. Gnathostomulida from America. Science, 163, 445-452.

RODRIGUE, N. \& LARTILLOT, N. 2014. Site-heterogeneous mutation-selection models within the PhyloBayes-MPI package. Bioinformatics, 30, 1020-1. 
ROY, S. W. \& IRIMIA, M. 2008. Rare Genomic Characters Do Not Support Coelomata: Intron Loss/Gain. Molecular Biology and Evolution, 25, 620-623.

SCHIEMANN, S. M., MARTIN-DURAN, J. M., BORVE, A., VELLUTINI, B. C., PASSAMANECK, Y. J. \& HEJNOL, A. 2017. Clustered brachiopod Hox genes are not expressed collinearly and are associated with lophotrochozoan novelties. Proc Natl Acad Sci U S A, 114, E1913-E1922.

SCHLEIP, W. 1929. Die Determination der Primitiventwicklung, Leipzig, Akademische Verlagsgesellschaft.

SCHNEIDER, S. Q. \& BOWERMAN, B. 2007. beta-Catenin asymmetries after all animal/vegetal- oriented cell divisions in Platynereis dumerilii embryos mediate binary cell-fate specification. Dev Cell, 13, 73-86.

SIMAKOV, O., MARLETAZ, F., CHO, S.-J., EDSINGER-GONZALES, E., HAVLAK, P., HELLSTEN, U., KUO, D.-H., LARSSON, T., LV, J., ARENDT, D., SAVAGE, R., OSOEGAWA, K., DE JONG, P., GRIMWOOD, J., CHAPMAN, J. A., SHAPIRO, H., AERTS, A., OTILlAR, R. P., TERRY, A. Y., BOORE, J. L., GRIGORIEV, I. V., LINDBERG, D. R., SEAVER, E. C., WEISBLAT, D. A., PUTNAM, N. H. \& ROKHSAR, D. S. 2013. Insights into bilaterian evolution from three spiralian genomes. Nature, 493, 526-531.

SONG, M. H., HUANG, F. Z., CHANG, G. Y. \& WEISBLAT, D. A. 2002. Expression and function of an even-skipped homolog in the leech Helobdella robusta. Development, $129,3681-92$.

TARAZONA, O. A., LOPEZ, D. H., SLOTA, L. A. \& COHN, M. J. 2019. Evolution of limb development in cephalopod mollusks. eLife, 8, e43828.

TARAZONA, O. A., SLOTA, L. A., LOPEZ, D. H., ZHANG, G. \& COHN, M. J. 2016. The genetic program for cartilage development has deep homology within Bilateria. Nature, 533, 86-9.

VELLUTINI, B. C., MARTIN-DURAN, J. M. \& HEJNOL, A. 2017. Cleavage modification did not alter blastomere fates during bryozoan evolution. BMC Biol, 15, 33 .

VERASZTO, C., UEDA, N., BEZARES-CALDERON, L. A., PANZERA, A., WILLIAMS, E. A., SHAHIDI, R. \& JEKELY, G. 2017. Ciliomotor circuitry underlying wholebody coordination of ciliary activity in the Platynereis larva. Elife, 6.

WANG, S., ZHANG, J., JIAO, W., LI, J., XUN, X., SUN, Y., GUO, X., HUAN, P., DONG, B., ZHANG, L., HU, X., SUN, X., WANG, J., ZHAO, C., WANG, Y., WANG, D., HUANG, X., WANG, R., LV, J., LI, Y., ZHANG, Z., LIU, B., LU, W., HUI, Y., 
LIANG, J., ZHOU, Z., HOU, R., LI, X., LIU, Y., LI, H., NING, X., LIN, Y., ZHAO, L., XING, Q., DOU, J., LI, Y., MAO, J., GUO, H., DOU, H., LI, T., MU, C., JIANG, W., FU, Q., FU, X., MIAO, Y., LIU, J., YU, Q., LI, R., LIAO, H., LI, X., KONG, Y., JIANG, Z., CHOURROUT, D., LI, R. \& BAO, Z. 2017. Scallop genome provides insights into evolution of bilaterian karyotype and development. Nature Ecology \&Amp; Evolution, 1, 0120.

WANNINGER, A. \& WOLLESEN, T. 2018. The evolution of molluscs. Biol Rev Camb Philos Soc.

WEISBLAT, D. A. \& KUO, D. H. 2014. Developmental biology of the leech Helobdella. Int $J$ Dev Biol, 58, 429-43.

WILSON, E. B. 1898. Considerations on Cell-lineage and Ancestral Reminiscence. Annals New York Academy of Sciences, XI, 1-27.

ZAKAS, C., DEUTSCHER, J. M., KAY, A. D. \& ROCKMAN, M. V. 2018. Decoupled maternal and zygotic genetic effects shape the evolution of development. eLife, 7, e37143.

ZANTKE, J., BANNISTER, S., RAJAN, V. B., RAIBLE, F. \& TESSMAR-RAIBLE, K. 2014. Genetic and genomic tools for the marine annelid Platynereis dumerilii. Genetics, 197, 19-31. 
Table 1. Exemplary spiral-cleaving research systems

\begin{tabular}{|c|c|c|c|c|}
\hline Clade & Example species & $\begin{array}{l}\text { Public } \\
\text { genome }\end{array}$ & $\begin{array}{l}\text { Functional } \\
\text { approaches }\end{array}$ & $\begin{array}{l}\text { Imaging } \\
\text { approaches }\end{array}$ \\
\hline \multirow[t]{3}{*}{ Annelida } & Capitella teleta & $\begin{array}{l}\text { Yes } \\
\text { (Simakov et } \\
\text { al., 2013) }\end{array}$ & $\begin{array}{l}\text { Yes (e.g. } \\
\text { CRISPR) (Neal } \\
\text { et al., 2019) }\end{array}$ & $\begin{array}{l}\text { Yes (Meyer et } \\
\text { al., 2010) }\end{array}$ \\
\hline & Helobdella robusta & $\begin{array}{l}\text { Yes } \\
\text { (Simakov et } \\
\text { al., 2013) }\end{array}$ & $\begin{array}{l}\text { Yes (e.g. } \\
\text { morpholino) } \\
\text { (Song et al., } \\
\text { 2002) }\end{array}$ & $\begin{array}{l}\text { Yes (Gline et } \\
\text { al., 2011) }\end{array}$ \\
\hline & Platynereis dumerilii & No & $\begin{array}{l}\text { Yes (e.g. } \\
\text { CRISPR) } \\
\text { (Bezares- } \\
\text { Calderon et al., } \\
2018 \text { ) }\end{array}$ & $\begin{array}{l}\text { Yes (Ozpolat et } \\
\text { al., 2017, } \\
\text { Veraszto et al., } \\
\text { 2017) }\end{array}$ \\
\hline \multirow[t]{2}{*}{ Mollusca } & Crepidula fornicata & No & $\begin{array}{l}\text { Yes (e.g. } \\
\text { CRISPR) (Perry } \\
\text { and Henry, } \\
\text { 2015) }\end{array}$ & $\begin{array}{l}\text { Yes (Lyons et } \\
\text { al., 2015) }\end{array}$ \\
\hline & Lymnaea stagnalis & $\begin{array}{l}\text { Yes } \\
\text { (Davison et } \\
\text { al., 2016) }\end{array}$ & $\begin{array}{l}\text { Yes (e.g. } \\
\text { CRISPR) (Abe } \\
\text { and Kuroda, } \\
\text { 2019) }\end{array}$ & $\begin{array}{l}\text { Yes (Abe et al., } \\
\text { 2009) }\end{array}$ \\
\hline Platyhelminthes & $\begin{array}{l}\text { Prostheceraeus } \\
\text { crozieri }\end{array}$ & No & No & $\begin{array}{l}\text { Yes (Girstmair } \\
\text { and Telford, } \\
\text { 2019) }\end{array}$ \\
\hline Nemertea & Cerebratulus lacteus & No & $\begin{array}{l}\text { Yes (e.g. } \\
\text { morpholino) } \\
\text { (Henry et al., } \\
2008 \text { ) }\end{array}$ & $\begin{array}{l}\text { Yes (Henry et } \\
\text { al., 2008) }\end{array}$ \\
\hline
\end{tabular}




\section{Figure legends}

Fig. 1. Spiralians and spiral cleavage. (A) Representatives of the major clades exhibiting spiral cleavage. From left to right, snail (Mollusca; picture by Beocheck), earthworm (Annelida; picture by Ryan Hodnett), flatworm (Platyhelminthes; picture by Sébastien Vasquez), and ribbon worm (Nemertea; picture by Bruno C. Vellutini). (B) Schematic representation of a 4-cell stage spiral cleaving embryo, depicting the four embryonic quadrants named with the letters A to D. (C) Schematic representation of a 8-cell stage spiral cleaving embryo, showing the small animal micromeres, the larger vegetal macromeres and the direction perpendicular to cleavage (red arrows) shifted $\sim 45^{\circ}$ with respect to the animalvegetal axis. (D) Schematic drawing of a 36-cell stage spiral cleaving nemertean embryo viewed from the animal view, illustrating the spiral-like arrangement of the micromeres and their cleavage planes. Drawing adapted from (Maslakova et al., 2004). In (B-D), drawings are not to scale and cell colours in (C) and (D) corresponds to the quadrants in (B).

Fig. 2. Spiralian phylogeny. (A) Spiralian topology based on (Marletaz et al., 2019), with a Gnathifera clade including Chaetognatha as sister to the remaining spiralians, which itself comprises three major clades: Tetraneuralia, Lophophorata and Parenchymia. (B) Spiralian topology based on (Laumer et al., 2019), with Gnathifera also comprising Chaetognatha, but Platyhelminthes branching off together with Gastrotricha in the clade Rouphozoa, intermediate to Gnathifera and the remaining spiralians. 


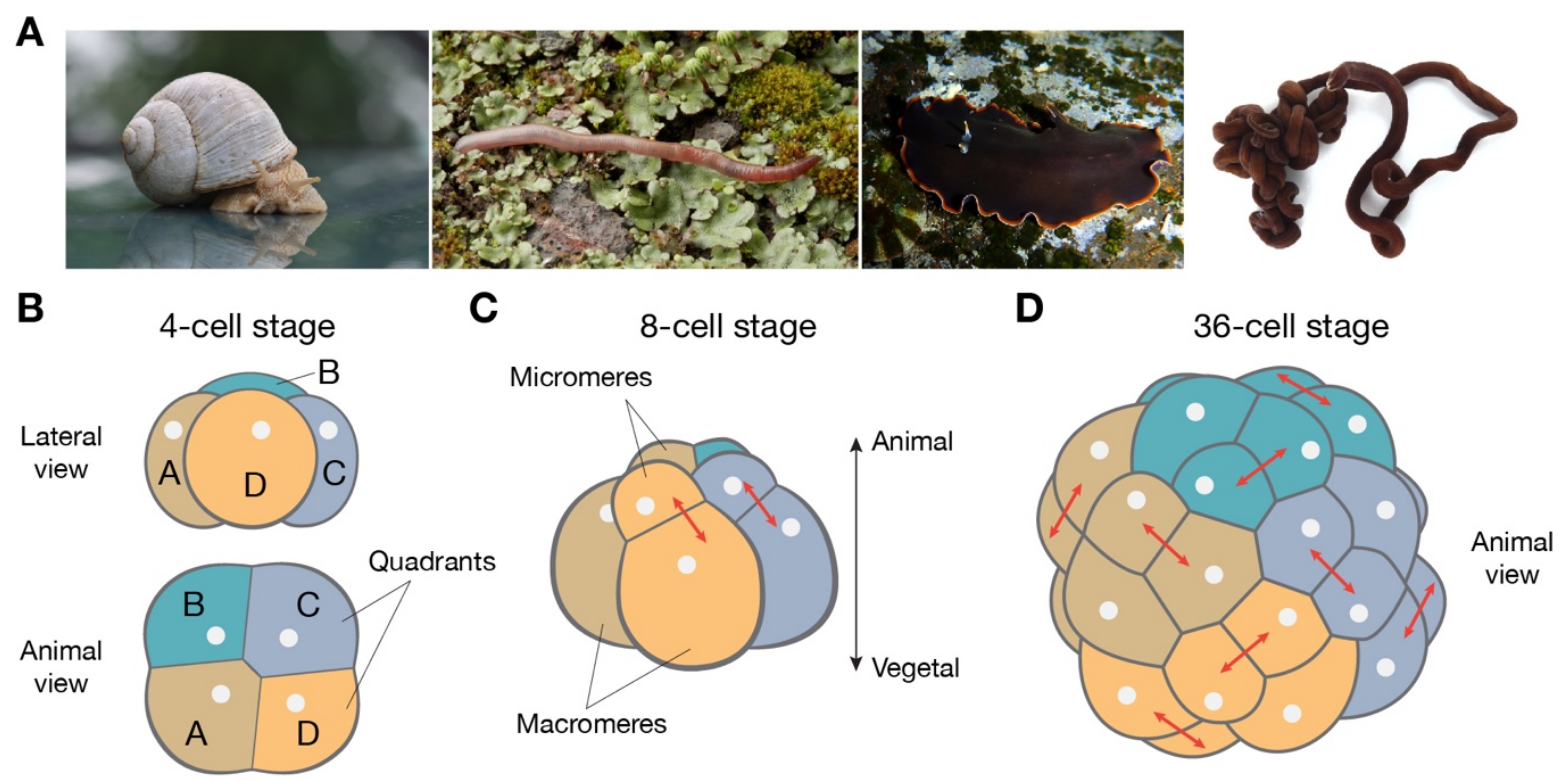

Figure 1 
A

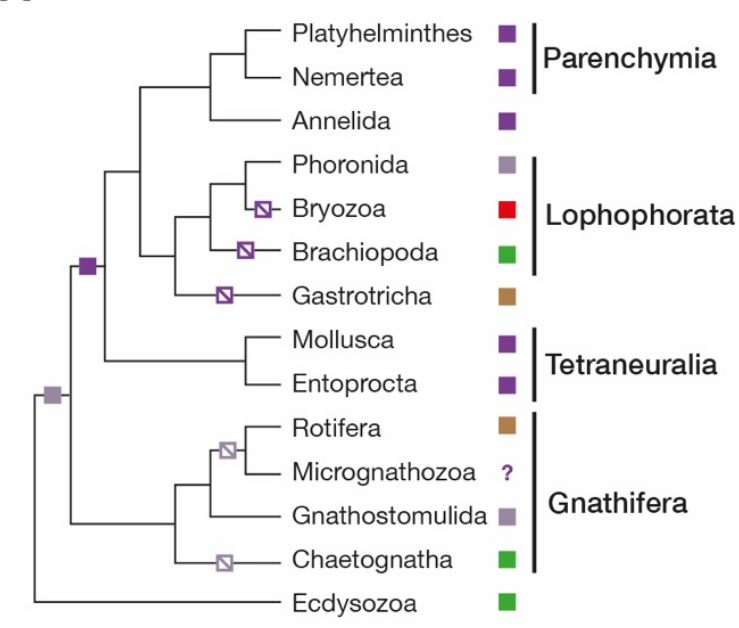

B

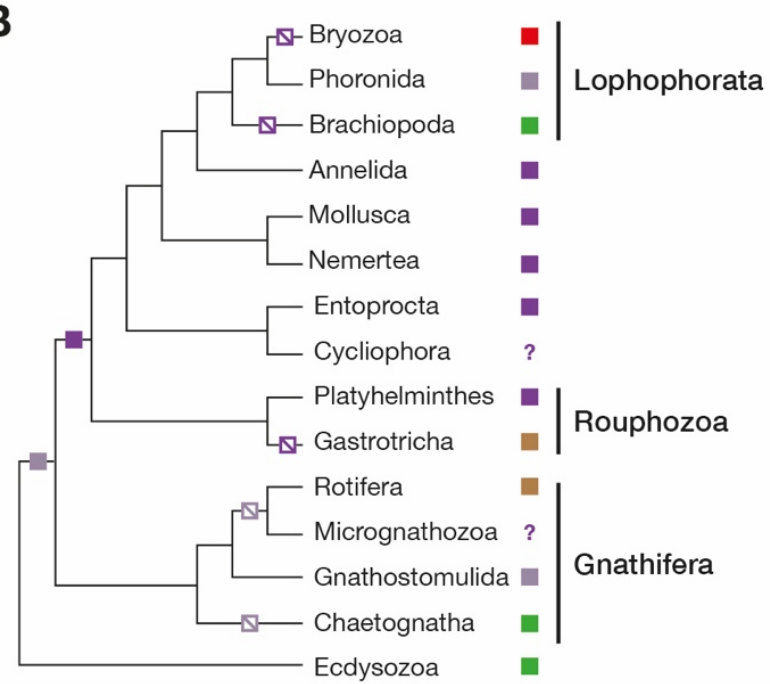

- Spiral cleavage present - Spiral cleavage absent

- Radial cleavage

Biradial cleavage

Figure 2 